American Journal of Applied Sciences 7 (12): 1599-1606, 2010

ISSN 1546-9239

(C) 2010 Science Publications

\title{
The Drying Kinetics of Chilies using a Rotating Fluidized Bed Technique
}

\author{
${ }^{1}$ Watcharin Dongbang, ${ }^{2}$ Worachest Pirompugd and ${ }^{1}$ Kittichai Triratanasirichai \\ ${ }^{1}$ Department of Mechanical Engineering, Khon Kaen University, \\ 123 Mittraparb Road, Muang, Khon Kaen 40002, Thailand \\ ${ }^{2}$ Department of Mechanical Engineering, Burapha University, \\ 169 Long-Hard Bangsaen Road, Muang, Chonburi 20131, Thailand
}

\begin{abstract}
Problem statements: The present study investigates experimentally the drying of chilies (Capsicum annuиm L.) with rotating fluidized bed technique and the biological properties: capsaicin content, moisture diffusivity and activation energy. Approach: The drying experiment was conducted at the drying air temperatures ranged $70-120^{\circ} \mathrm{C}$ and the drying air velocity was fixed at $1.8 \mathrm{~m} \mathrm{sec}^{-1}$, while the layer's height was fixed at $4 \pm 0.5 \mathrm{~cm}$. The chilies were dried starting $350 \pm 5 \% \mathrm{db}$ down to $10 \pm 1 \% \mathrm{db}$. Results: The drying time requested to dry chilies ranged $69-257 \mathrm{~min}$. The average capsaicin content of dried chilies was decreased starting 2725.4 down to $1617.4 \mathrm{ppm}$. The effective diffusivity and activation energy were also described. Conclusion: Drying air temperature was significant factor on the decreasing of moisture content, capsaicin content and redness of dried chilies. All samples can be marketable.
\end{abstract}

Key words: Rotating Fluidized Bed (RFB), drying kinetics, dried chilies, moisture diffusivity, drying air temperature, Capsicum aпnиит L., centrifugal fluidized, sunlit drying, linear logarithmic, cylindrical food

\section{INTRODUCTION}

The chilies are commonly used as condiment and they are the ripe fruits of the species of genus capsicum (Amaroek et al., 2010). After harvest, chilies contained high moisture estimated $400 \% \mathrm{db}$ (Amaroek et al., 2010); nevertheless, moisture content of $16 \% \mathrm{db}$ were acceptable in the export market (Amaroek et al., 2010). Then, chilies must be dried for making chili powder and for keeping in the short or long term storages.

A Rotating Fluidized Bed (RFB) which one of among of fluidized bed techniques is an air-distributor that can be rotated about its axis of symmetry with airflow introduced in the inward direction of the radius to fluidize the bed. Instead of having a fixed gravity field as in a conventional fluidized bed, the body force in a centrifugal bed becomes an adjustable parameter that is determined by the rotating speed and airdistributor radius. By using the strong centrifugal field much greater than gravity, the particle bed is able to withstand a large amount of airflow without serious formation of large bubbles and the gas-solid contract at high airflow is improved (Abdullah et al., 2010). The drying kinetics food from RFB were found only a few samples in published literature, e.g., soybean, green bean and rice (Chen et al., 1999 and Elmi et al., 2009) that almost sphere.

On the other hand, the cylindrical food, such as, chilies are scanty; in addition, the capsaicin of dried chilies based on drying temperature are scanty, too.

For the objectives of this study are (i) to investigate experimentally the drying kinetics of chilies in RFB technique, (ii) and to investigate the capsaicin content in dried chilies, moisture diffusivities and activation energies.

\section{MATERIALS AND METHODS}

Sample: The chilies (Capsicum annuum L.) which are freshly obtained from the market (average length of $65 \pm 5 \mathrm{~mm}$ and average diameter of $7.8 \pm 2 \mathrm{~mm}$ ) are used in this study. The initial moisture contents was measured by AOAC (2000) 930.04 method (Stephen and Emmanuel, 2009; Ibrahim et al., 2009) where the Central Laboratory (Thailand) Co., Ltd., Khon Kaen Branch, Thailand, that certificated from the laboratory accreditation with ISO/IEC 17025.

Experimental apparatus: The Rotating Fluidized Bed (RFB) technique or so-called a centrifugal fluidized bed technique can be used to dry several grains. The grains

Corresponding Author: Kittichai Triratanasirichai, Department of Mechanical Engineering, Khon Kaen University, 123 Mittraparb Road, Khon Kaen 40002, Thailand 
are introduced inside an air-distributor and are force to the wall by a centrifugal force due to the rotation of the air-distributor. The air flows radially inward through the air-distributor and the forces on the grain (Fig. 1) are balanced by the airflow (drag force and buoyancy force) and the centrifugal force (Watanoa et al., 2003; Elmi et al., 2009; Opafunso et al., 2009). The variable defined $r$ is radius of an air-distributor (m) and $\omega$ is an angular velocity $\left(\mathrm{rad} \mathrm{sec}^{-1}\right)$. The air-distributor always rotates in the clockwise direction in this study.

For RFB apparatus can be seen at Fig. 2, it is a schematic diagram of the experimental apparatus for this study. The air-distributor with $400 \mathrm{~mm}$ diameter and $200 \mathrm{~mm}$ width can be rotated around a horizontal axis. The rotating speed can be adjustable for the several drying conditions. Additional, the dimension of side surface of air-distributor are $2.5 \mathrm{~mm}$ in hole and $38.5 \%$ in open area. The rotating speed can be adjusted by a frequency inverter and measured by RPM-meter (Tachometer Digital Meter, DTO6234N and Germany) with an accuracy of $\pm 0.1 \%$. For visualizing, the transparent glass was installed at the end wall. The high-speed video camera was observed the fluidization behaviors. For exhaust air, a filter of $100 \mathrm{~mm}$ diameter was located at the center of the air-distributor. The drying air was blown by a blower of 5 HP which was adjusted the rotating speeds by frequency inverter. The drying airflow was measured by an orifice meter with U-shaped manometer. The pressure drop through the bed was measured by a Ushaped manometer. An electric heater, the drying air was heated by an electric heater of $5 \mathrm{~kW}$ and adjusted by PID control (Suntree, SG6, USA) with an accuracy of $\pm 0.1 \%$. For temperature, J-type iron-constantan thermocouple was used: thermometer indicators (NS, YB05C-A1 and China) with an accuracy of $\pm 0.05 \%$. An apparatus was constructed for the experiment in this study it was installed at the Khon Kaen University, Thailand.

Drying method: For drying with RFB, the procedures were defined as following. First of all, an electric heater was started upon drying conditions with the six intervals of the drying air temperatures; namely, 70, $80,90,100,110$ and $120^{\circ} \mathrm{C}$ at the drying air velocity of $1.8 \mathrm{~m} \mathrm{sec}^{-1}$.

An experimental apparatus was operated with the operation time of $60 \mathrm{~min}$ for stabilizing the drying condition. The second, the $2 \mathrm{~kg}$ samples (estimated $4 \pm 0.5 \mathrm{~cm}$ of the bed layer height) were filled into the air-distributor (drying chamber) they are an initial weight of the sample. The third, the air-distributor was started with the rotating speed of $106 \pm 0.1 \mathrm{rpm}$.

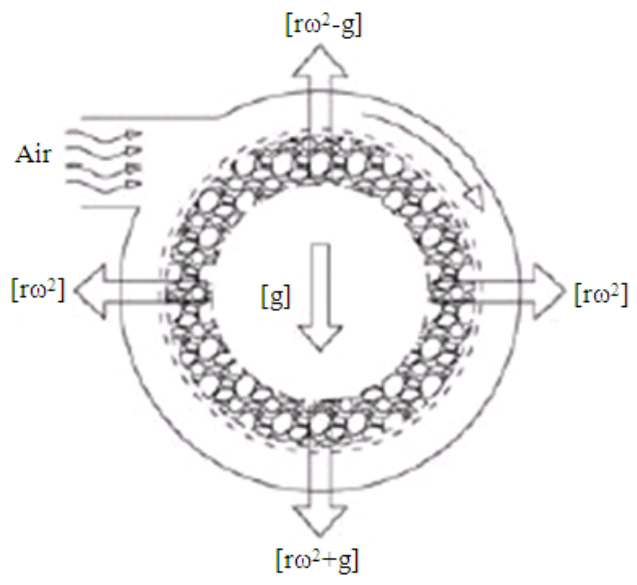

Fig. 1: The several forces in RFB technique

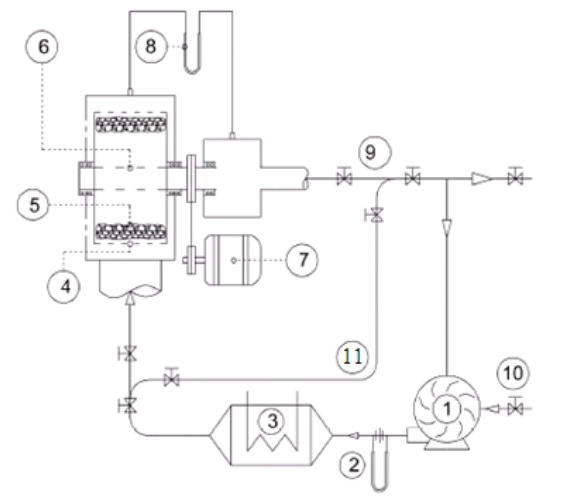

The numeral meaning:

(1) Blower; (2) Orifice meter, U-tube; (3) Electric heater

(4) Air-distributor; (5) Particle bed; (6) Rotational filter;

(7) Motor; (8) U-tube; (9) Recycle air; (10) Fresh air; (11) Bypass air

Fig. 2: Diagram of RFB system

Finally, the moisture loss was recorded every $10 \mathrm{~min}$ during drying processes by a digital balance (OHAUS, PA512, USA) with an accuracy of $\pm 0.01 \mathrm{~g}$. The samples are dried from the initial moisture content of $350 \pm$ $5 \% \mathrm{db}$ down to moisture of $10 \% \pm 1$ d.b. The experiment was repeated three times and the average data was evaluated for analysis.

For drying with sunlight, a kilogram of chilies were exposed under the sunlight. The samples were kept in a container at night. This process was conducted continuously in a span of 12-15 days.

Theoretical considerations: The moisture movement inside the particle was developed based on Fick's second law of diffusion (Quasem et al., 2009; Yahya et al., 2010). The chilies are assumed to the infinite length cylinder which is the equation of conservation of energy is: 
Am. J. Applied Sci., 7 (12): 1599-1606, 2010

$$
\frac{\partial M}{\partial t}(r, t)=D_{\text {eff }}\left[\frac{\partial^{2} M}{\partial r^{2}}+\frac{c}{r} \frac{\partial M}{\partial M}\right]
$$

The variable, $\mathrm{M}$ is the moisture content at anytime in unit of decimal of dry basis $(\mathrm{db}), \mathrm{D}_{\text {eff }}$ is effective moisture diffusivity of grains $\left(\mathrm{m}^{2} \mathrm{sec}^{-1}\right), \mathrm{t}$ is drying time (s), $r$ is radial distance from center of grains (m) and $\mathrm{c}$ is constant. Assuming uniform initial moisture distribution and negligible external resistance, the solution proposed by following (Amaroek et al., 2010):

$$
\mathrm{MR}=\sum_{\mathrm{n}=1}^{\infty} \frac{4}{\mathrm{~b}_{\mathrm{n}}^{2}} \exp \left[-\frac{\mathrm{b}_{\mathrm{n}}^{2} \mathrm{D}_{\text {eff }} \mathrm{t}}{\mathrm{r}_{\mathrm{c}}^{2}}\right]
$$

The variable, $r_{s}$ is radius of grain $(m), M$ is average moisture content at anytime (dry basis) and $b$ is root of Bessel's function of order zero. For long drying times (setting $\mathrm{n}=1$ ), an Eq. 2 can be further simplified to a straight line equation as (Sayyar et al., 2009):

$$
\ln (\mathrm{MR})=\ln \left[\frac{4}{\mathrm{~b}^{2}}\right]\left[-\frac{\mathrm{b}^{2} \mathrm{D}_{\text {eff }}}{\mathrm{r}_{\mathrm{c}}^{2}}\right] \mathrm{t}
$$

To determine the effective diffusivity coefficient, $D_{\text {eff }}$, the slope of the relationships between $\ln (\mathrm{MR})$ and time (Eq. 3) is computed and then $D_{\text {eff }}$ is calculated by the following equation:

$$
\text { Slope }=\frac{b^{2} D_{\text {eff }}}{r_{c}^{2}}
$$

Moistures ratio of sample during the thin-layer drying experiment is calculated with the following equation (Brooks et al., 2008; Charmongkolpradit et al., 2010):

$$
M R=\frac{M-M_{e}}{M_{o}-M_{e}}
$$

The equilibrium moisture content, $\mathrm{M}_{\mathrm{e}}$, can be negligible because it is very small (Quasem et al., 2009; Sghaier et al., 2009) compared with $\mathrm{M}$ or $\mathrm{M}_{\mathrm{o}}$. Consequently, the Eq. 6 can be rewritten to:

$$
\mathrm{MR}=\frac{\mathrm{M}}{\mathrm{M}_{\mathrm{o}}}
$$

The moisture diffusivity $\left(D_{\text {eff }}\right)$ increases with the increase in drying temperature; (Hii et al., 2009; Sayyar et al., 2009). The temperature effect is modeled using well know Arrhenius type relationship (Sayyar et al., 2009).
$\mathrm{D}_{\text {eff }}=\mathrm{D}_{\mathrm{o}} \exp \left[\frac{\mathrm{E}_{\mathrm{a}}}{\mathrm{RT}}\right]$

By taking the natural logarithm of both sides, the above exponential form of Arrhenius can be transfigured into a linear Logarithmic form:

$\ln \left(D_{\text {eff }}\right)=\ln \left(D_{o}\right)-\left[\frac{E_{a}}{R}\right]\left[\frac{1}{T}\right]$

The variable, $E_{a}$ is the activation energy $(\mathrm{kJ}$ $\mathrm{kgmol}^{-1}$ ) and $\mathrm{D}_{\mathrm{o}}$ is the Arrhenius's factor (Sayyar et al., 2009; Sghaier et al., 2009). $\left(\mathrm{m}^{2} \mathrm{sec}^{-1}\right)$ that were determined by plotting $\ln \left(\mathrm{D}_{\text {eff }}\right)$ versus $(1 / \mathrm{T})$. The variable, $\mathrm{R}$ is universal gas constant $(8.314 \mathrm{~kJ}$ kgmol. $\mathrm{K}^{-1}$ ) and $\mathrm{T}$ is absolute temperature $(\mathrm{K})$. Analysis of variance was carried out to find the effects $(p<0.05)$ of drying air temperature.

\section{RESULTS}

Drying kinetics: The comparison to the drying kinetics of six intervals of drying air temperatures have shown the rate of moisture reduction that was greatest at a highest temperature (Fig. 3). It responded the influence of drying temperature on the ability to diffuse moisture $(p<0.05)$. It can be described after that have ventilated the gas velocity in RFB technique, the turbulence and mixing of the fluidized particles were intensified. Then, the gas film on the particles becomes thin, so the gassolid heat transfer was improved (Kowalski et al., 2010). In addition, after increased the temperature of drying air from $70-120^{\circ} \mathrm{C}$, the latent heat was intensified, so the dehydration from the moist produce was improved (Bovornsethanan and Wongwises, 2007; Brooks et al., 2008; Theansuwan et al., 2008).

The researchers have been recently reported the same phenomenon for other grain, such as red chilies (Anwarul Huq and Arshad, 2010), Bird's chilies (Amaroek et al., 2010), chopped coconut (Madhiyanon et al., 2009) and apple (Marjan et al., 2010). The drying time to dry chilies from initial moisture content of approximately $350 \pm 5 \% \mathrm{db}$ to final moisture content of approximately $10 \pm 1 \% \mathrm{db}$ were $257,163,131,98,78$ and $69 \mathrm{~min}$ at $70,80,90,100,110$ and $120^{\circ} \mathrm{C}$ of drying air temperature, respectively. It was reported that the using of another dryer took $13 \mathrm{~h}$ to dry chilies from $325-10.5 \% \mathrm{db}$ at $65^{\circ} \mathrm{C}$ of drying air temperature (Amaroek et al., 2010; Mazloomi et al., 2010) and 
$106.7 \mathrm{~min}$ to dry the sliced bird's eye chilies to $16 \% \mathrm{db}$ at $70^{\circ} \mathrm{C}$ of drying air temperature (Omar et al., 2008). Initially, the abundance of free water on the produce surface contributed the effortless moisture liberation; however, much more difficult it might be to expel water after that, when the produce surface becomes harder due to shrinkage (Kowalski et al., 2010).

\section{DISCUSSION}

Redness: The redness of dried chilies at different conditions was observed. The results shown the redness deterioration after drying both RFB technique and sunlit drying were investigated. They are differences in redness from two different methods; namely, the dried chilies from sunlit drying appear the light red; on the other hand, from a RFB appear dark redness (Fig. 4).

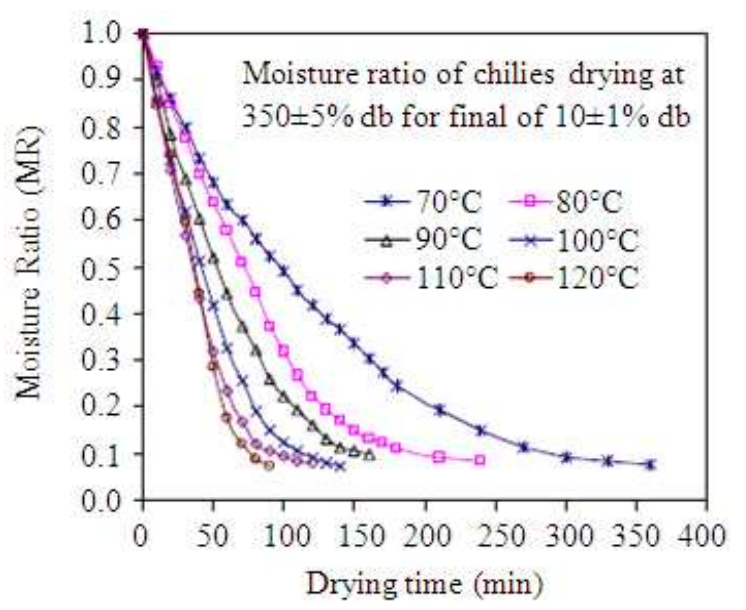

Fig. 3: Experimental drying curves relationship between moisture ratio and drying time

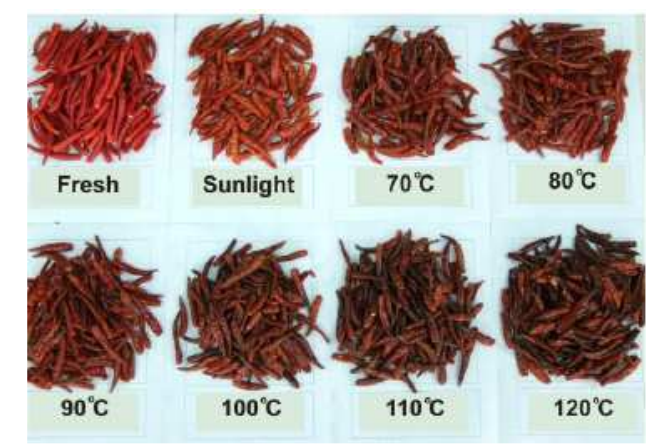

Fig. 4: The comparable redness of the dried chilies (Capsicum aпnиum $\mathrm{L}$ )
When the drying air temperature increases starting $70-120^{\circ} \mathrm{C}$, the redness is also affected adversely; on the other hand, it can be marketable. It may be due to the oxidation of carotenoid pigments at the elevated temperatures. This behavior was similarly reported by Omar et al. (2008). The chilies dried under the sunlight for about 12-15 days can be registered the moisture content of $10 \pm 1 \% \mathrm{db}$. This drying kinetics was similar reported by Amaroek et al. (2010). Nevertheless, the drying time for sunlit drying is far too long compared to drying with a RFB with only requires a few hours.

Capsaicin content: Capsaicin is the main capsaicinoid in chilies, followed by Dihydrocapsaicin. These two compounds are also about twice as potent to the taste and nerves while the minor capsaicinoids are Nordihydrocapsaicin, Homodihydro-capsaicin, Homocapsaicin and Nonivamide (Cisneros-Pineda et al., 2007; Ornela-Paz et al., 2010). The analysis of capsaicinoids content in this study represented to the capsaicin (8-Methyl-N-vanillyl-trans-6-nonenamide) in dried chilies (Capsicum annuum L.). The method to investigate the capsaicinoid content was made by HPLC based on AOAC (2005) 995.03 in house method and tested at Central Laboratory (Thailand) Co., Ltd., Khon Kaen Branch, Thailand-that certificated from the laboratory accreditation with ISO/IEC 17025. Each dried chilies was analyzed in four replications while the level of capsaicin content with the use of $\mathrm{ppm}$ $\left(\mathrm{mg} \mathrm{kg}^{-1}\right)$ unit was also determined. The volume of the lowest significant difference was determined with $\mathrm{p} \leq 0.05$. They were determined in among dried chilies in difference of drying air temperature and represented more than $70 \%$ of the total capsaicinoids in the dried chilies (Omar et al., 2008; Pompimon et al., 2009). For the first repeated sample at drying air temperature of $70^{\circ} \mathrm{C}$ allowed us to infer that peak at RetTime of 3.403 min and $4.341 \mathrm{~min}$ for capsaicin content of $2709.1 \mathrm{ppm}$ and dihydrocapsaicin content of $1488.6 \mathrm{ppm}$, respectively while other detail can be seen in Fig. 5 and Fig. 6; in addition, the results of other repeated drying can be seen in Table 1. The results shown the average capsaicin contents of dried chilies decreased from 2725.4 to $1617.4 \mathrm{ppm}$ as the drying air temperature increased from $70-120^{\circ} \mathrm{C}$ while the average capsaicin of dried chilies after sunlit drying method are $2943.8 \mathrm{ppm}$. It clearly shows that the capsaicin of chilies was affected adversely when higher temperatures were used for drying $(p<0.05)$. Similar results were quoted in the case of red chilies drying (Amaroek et al., 2010). The polynomial equation was fitted capsaicin "Cap" (ppm) versus drying air temperature " $T$ " that can be seen at Fig. 5 as follows:

Cap $=0.3495 \mathrm{~T} 2-86.924 \mathrm{~T}+7050.132$

where, $R^{2}=0.982$ and temperature $(\mathrm{T})$ ranged $70-120^{\circ} \mathrm{C}$. 
Am. J. Applied Sci., 7 (12): 1599-1606, 2010

Table 1: The capsaicin contents at different drying air temperatures in dried chilies after dried starting $350 \pm 2-10 \pm 1 \% \mathrm{db}$

\begin{tabular}{lllll}
\hline & \multicolumn{2}{c}{ Capsaicin contents $(\mathrm{ppm})$} & & \\
Drying air temperature $\left({ }^{\circ} \mathrm{C}\right)$ & 1st repeated & 2nd repeated & 3rd repeated & Average \\
\hline 70 & 2709.1 & 2712.1 & 2755.0 & 2725.4 \\
80 & 2326.9 & 2203.4 & 2246.5 & 2259.0 \\
90 & 2059.8 & 2007.6 & 2026.9 & 2031.5 \\
100 & 1852.6 & 1892.7 & 1967.8 & 1904.4 \\
110 & 1782.7 & 1750.1 & 1730.2 & 1754.3 \\
120 & 1516.1 & 1665.1 & 1671 & 1617.4 \\
Sunlit drying & 2924.2 & 2963.3 & - & 26.4 \\
\hline
\end{tabular}

Note: The 1st, 2nd and 3rd are the repeated drying sample, respectively. "STD" and "Sunlight" are the standard deviation and chilies drying by sunlight, respectively

Table 2: The values of drying time and average moisture diffusivities, $D_{\text {eff }}$ at different temperatures

\begin{tabular}{lll}
\hline Temperature $\left({ }^{\circ} \mathrm{C}\right)$ & Drying time $(\mathrm{min})$ & Deff $\left(\mathrm{m}^{2} \mathrm{sec}^{-1}\right)$ \\
\hline 70 & 257 & $0.42 \times 10^{-9}$ \\
80 & 163 & $0.72 \times 10^{-9}$ \\
90 & 131 & $0.89 \times 10^{-9}$ \\
100 & 98 & $1.11 \times 10^{-9}$ \\
110 & 78 & $1.51 \times 10^{-9}$ \\
120 & 69 & $1.67 \times 10^{-9}$ \\
\hline
\end{tabular}

Table 3: Moisture diffusivities and activation energy of chilies and other products

\begin{tabular}{lllc}
\hline Products & $\begin{array}{l}\text { Temperature } \\
\left({ }^{\circ} \mathrm{C}\right)\end{array}$ & $\begin{array}{l}\mathrm{D}_{\text {eff }} \times 109 \\
\left(\mathrm{~m}^{2} \mathrm{sec}^{-1}\right)\end{array}$ & $\begin{array}{l}\mathrm{E}_{\mathrm{a}} \\
\left(\mathrm{kJ} \mathrm{mol}^{-1}\right)\end{array}$ \\
\hline $\begin{array}{l}\text { Chilies (Present study) } \\
\begin{array}{l}\text { Black tea } \\
\text { (Panchariya } \text { et al., 2002) }\end{array}\end{array}$ & $\begin{array}{l}70-120 \\
80-120\end{array}$ & $0.42-1.67$ & 30.39 \\
$\begin{array}{l}\text { Yong coconut } \\
\text { (Madamba, 2003) }\end{array}$ & $50-70$ & $0.17-0.55$ & 406.02 \\
$\begin{array}{l}\text { Parboiled wheat } \\
\text { (Mohaprtra and Rao, 2005) }\end{array}$ & $40-60$ & $0.12-0.28$ & 65.16 \\
$\begin{array}{l}\text { Corn } \\
\text { (Doymaz and Pala, 2003) }\end{array}$ & $55-75$ & $0.09-0.17$ & 29.56 \\
$\begin{array}{l}\text { Apple pomace } \\
\text { (Wang } \text { et al., 2007) }\end{array}$ & $75-105$ & $2.02-3.93$ & 24.51 \\
\hline
\end{tabular}

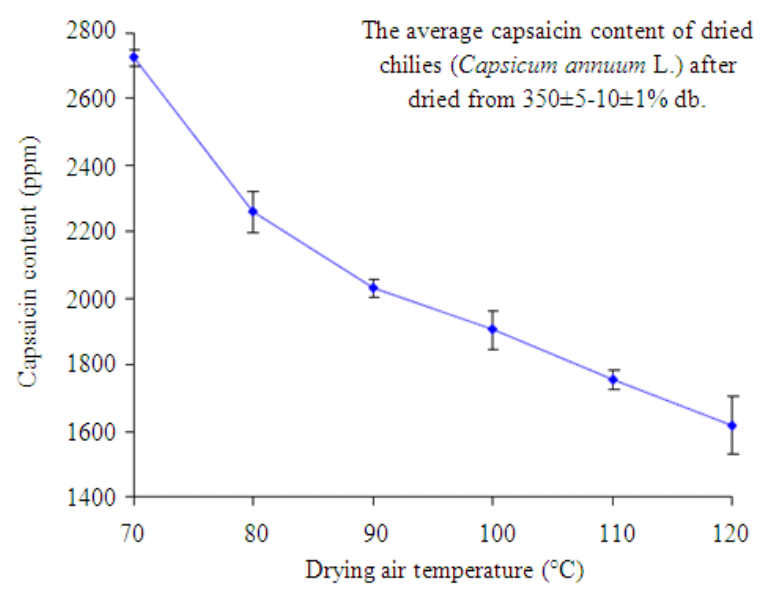

Fig. 5: Relationship between capsaicin Vs temperature
Moisture diffusivity: The Fick's law can be adopted into the simulation (Eq. 2). The values of $D_{\text {eff }}$ associated with temperatures of $70-120^{\circ} \mathrm{C}$ (Table 2) are $0.42 \times 10-9$ to $1.67 \times 10-9 \mathrm{~m}^{2} \mathrm{sec}^{-1}$. As expected, drying air temperature had an appreciable effect on $D_{\text {eff }}$, which increased vigorously with increase in temperature that can be fitted in linear equation as following.

$D_{\text {eff }}=1.1 \times 10^{-11} \mathrm{~T}-6.28$

Where, $R^{2}=0.984$ and temperature $(T)$ ranged 70 $120^{\circ} \mathrm{C}$. It is important to underline that the typical values of $D_{\text {eff }}$ for food and biological materials (Table 3). Due to its effective mixing mechanism, the rotating fluidized bed can expedite heat and mass transfer between drying air and chilies.

The more rapidly heat was conveyed to the product and the greater mass transfer rate was achievable; as a result, $D_{\text {eff }}$ was enhanced. In addition, the relatively length of the dried chilies (length of $65 \pm 5 \mathrm{~mm}$ ) may aid dehydration, because the $\mathrm{D}_{\text {eff }}$ dominate mass transfer and the characteristic length played crucial roles.

Characteristic length is inversely related to internal mass transfer resistance (Karim and Hawlader, 2005; Madhiyanon et al., 2009), so that the longer the length of chilies to be dried, the greater moisture immigration to the chilies surface.

Activation energy: The ln-values of activation energy, analyzed by Arrhenius expression (Eq. 7) and plotted versus the reciprocal of absolute temperature (Fig. 7) has shown a linear relationship. The activation energy, $E_{a}$, gained from the line slop yielded a value of $30.39 \mathrm{~kJ}$ $\mathrm{mol}^{-1}$ and the pre-exponential, $\mathrm{D}_{\mathrm{o}}$, derived from the axis intercept point is $1.99 \times 10-5 \mathrm{~m}^{2} \mathrm{sec}^{-1}$. As summarized in Table 3, the comparisons of $E_{a}$ with other researcher for a diversity of agricultural product are suggested. The present values shown the black tea it was rather high. 


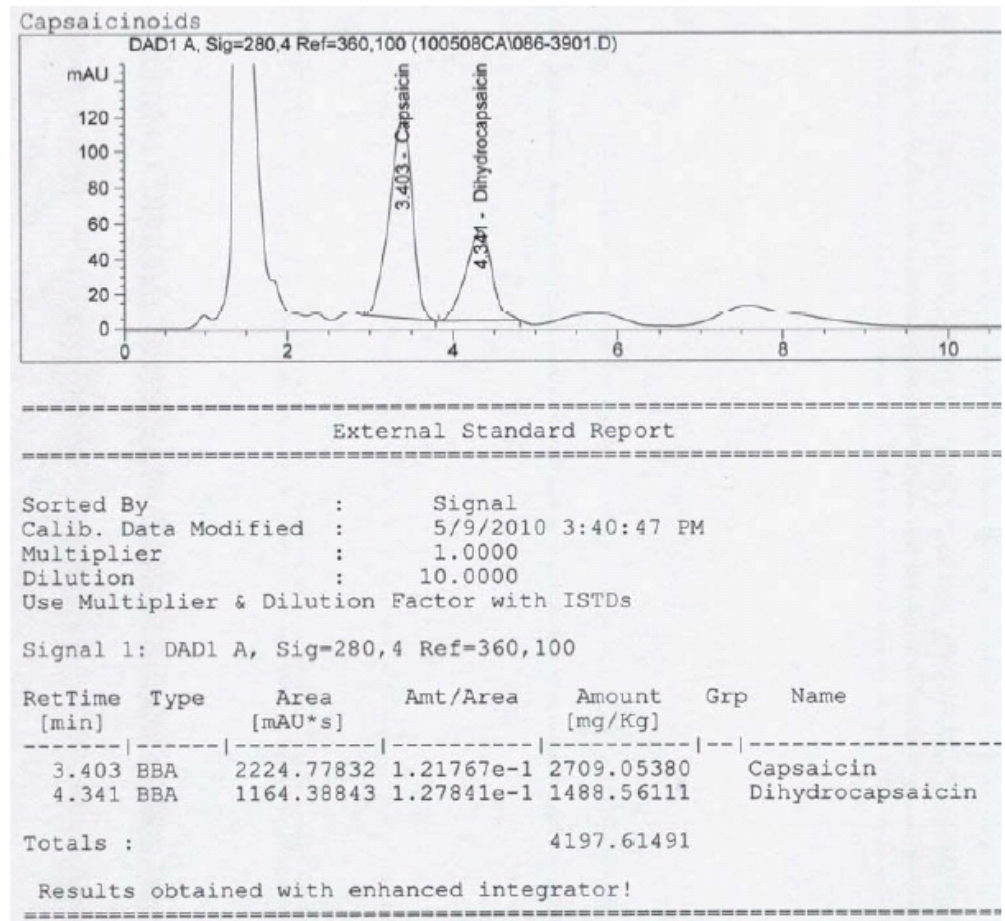

Fig. 6: Chromatogram of capsaicin and dihydrocapsaicin in dried chilies

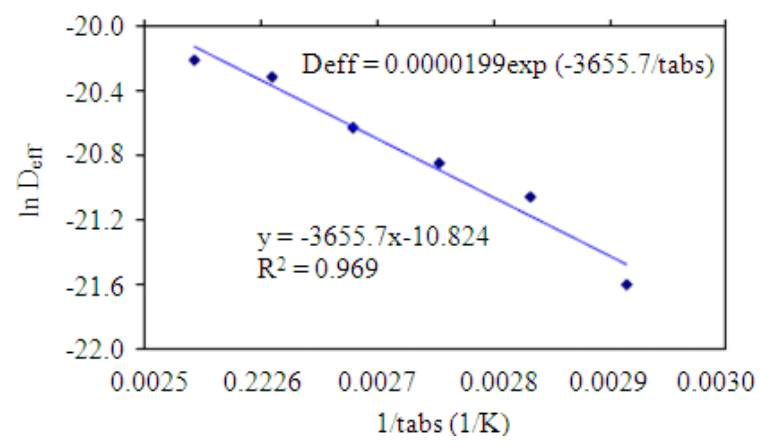

Fig. 7: Arrhenius-type relationship between moisture diffusivity and reciprocal of absolute temperature

\section{CONCLUSION}

The chilies drying on the Rotating Fluidized Bed (RFB) technique can be concluded as following. Drying kinetic, the influence of drying temperature on the ability to diffuse moisture that can be described after that have ventilated the gas velocity in RFB technique, the turbulence and mixing of the fluidized particles were intensified; in addition, after increased the temperature of drying air from $70-120^{\circ} \mathrm{C}$, the latent heat was intensified, so the dehydration from the moist produce was improved (Sghaier et al., 2009; Brian Boswell et al., 2009; Singh and Pandey, 2010). Redness, they are differences in redness from two different methods; namely, the dried chilies from sunlit drying appear the light red; on the other hand, from a RFB appear dark redness. It may be due to the oxidation of carotenoid pigments at the elevated temperatures (Amaroek et al., 2010). Capsaicin, the average capsaicin contents of dried chilies decreased from 2725.4-1617.4 ppm as the drying air temperature increased while the average capsaicin of dried chilies after sunlit drying method are $2943.8 \mathrm{ppm}$. It clearly shows that the capsaicin of chilies was affected adversely when higher temperatures were used for drying. Similar results were quoted in the case of red chilies drying (Amaroek et al., 2010). Moisture diffusivities, $\mathrm{D}_{\text {eff, }}$ drying air temperature had an appreciable effect on its and increased vigorously with increase in temperature. Activation energy, $\mathrm{E}_{\mathrm{a}}$, gained from the line slop yielded a value of $30.39 \mathrm{~kJ} \mathrm{~mol}^{-1}$.

\section{ACKNOWLEDGEMENT}

The researchers wish to thank the Center for Alternative Energy Research and Development (AERD), KhonKaen University, Thailand. That supported the financial research under project of $\mathrm{R} 10 / 2552$. 


\section{REFERENCES}

Abdullah, E.C., A.M. Salam and A.R. Aziz, 2010. Cohesiveness and flowability properties of silica gel powder. Phy. Int., 1: 16-21. DOI: 10.3844/pisp.2010.16.21

Amaroek, S., N.T. Umpon, K. Wantanajittikul and S. Auephanwiriyakul, 2010. Moisture content prediction of dried longan aril from dielectric constant using multilayer perceptrons and support vector regression. Am. J. Applied Sci., 7: 1387-1392. DOI: 10.3844/ajassp.2010.1387.1392

Anwarul Huq, A.S.M. and F.M. Arshad, 2010. Technical efficiency of chili production. Am. J. Applied Sci., 7: 185-190. DOI: 10.3844/ajassp.2010.185.190

Boswell, B. and T.T. Chandratilleke, 2009. Air-cooling used for metal cutting. Am. J. Applied Sci., 6: 251-262. DOI: 10.3844/ajassp.2009.251.262

Bovornsethanan, S. and S. Wongwises, 2007. Drying parawood with superheated steam. Am. J. Applied Sci., 4: 215-219. DOI: 10.3844/ajassp.2007.215.219

Brooks, M.S., N.H. Abou El-Hana and A.E. Ghaly, 2008. Effects of tomato geometries and air temperature on the drying behavior of plum tomato. Am. J. Applied Sci., 5: 1369-1375. DOI: 10.3844 /ajassp.2008.1369.1375

Charmongkolpradit, S., K. Triratanasirichai and N. Srihajong, 2010. Drying characteristics of chili using continuous fluidized-bed dryer. Am. J. Applied Sci., 7: 1300-1304. DOI: 10.3844/ajassp.2010.1300.1304

Chen, G., W. Wang, H. Yan and Z. Wang, 1999. Experimental research on mass transfer in a centrifugal fluidized bed dryer. Drying Technol., 17: 1845-1857. DOI: 10.1080/07373939908917656

Cisneros-Pineda, O., L.W. Torres-Tapia, L.C. GutirrezPacheco et al., 2007. Capsaicinoids quantification in chili peppers cultivated in the state of Yucatan, Mexico. Food Chem., 104: 1755-1760. DOI: 10.1016/j.foodchem.2006.10.076

Doymaz, I. and M. Pala, 2003. The thin-layer drying characteristics of cone. J. Food Eng., 60: 125-130. DOI: 10.1016 /S0260-8774(03)00025-6

Elmi, A., B. Mehdi, C. Madramootoo, R. Dam and D. Smith, 2009. Long-term effect of conventional and notillage production systems on nitrous oxide fluxes from corn (Zea mays L.) field in southwestern quebec. Am. J. Environ. Sci., 5: 238-246. DOI: 10.3844/ajessp.2009.238.246

Hii, C.L., C.L. Law and M. Cloke, 2009. Modeling using a new thin layer drying model and product quality of cocoa. J. Food Eng., 90: 191-198. DOI: 10.1016/j.jfoodeng. 2008.06.022
Ibrahim, M., K. Sopian and W.R.W. Daud, 2009. Study of the drying kinetics of lemon grass. Am. J. Applied Sci., 6: 1070-1075. DOI: 10.3844/ajassp.2009.1070.1075

Karim, A.M. and M.N.A. Hawlader, 2005. Mathematical modeling and experimental investigation of tropical fruits drying. Int. J. Heat Mass Transfer, 48: 4914-4925. DOI: 10. 1016/j.jheatmasstransfer.2005.04.035

Kowalski, Z., Z. Wzorek and M. Banach, 2010. Removal of unpleasant odorous substances from smoke produced by smoke curing houses. Am. J. Environ. Sci., 6: 115-123. DOI: 10.3844/ajessp.2010.115.123

Madamba, P.S., 2003. Thin-layer drying models for osmotically pre-dried young coconut. Dry. Technol., 21: 1759-1780. DOI: 10.1081/DRT120025507

Madhiyanon, T., A. Phila and S. Soponronnarit, 2009. Models of fluidized bed drying for thin-layer chopped coconut. Applied Thermal Eng., 29: 2849-2854. DOI: 10.1016/j.applthermaleng.2009.02.003

Marjan, J., J. Endan, K.A. Abbas and F. Arvin, 2010. Development of a semi-industrial multi fruit dryer system using simultaneous intelligent control. Am. J. Applied Sci., 7: 160-166. DOI: 10.3844/ajassp.2010.160.166

Mazloomi, M., A.S. Hassan, P.N. Bagherpour and M.R. Ismail, 2010. Influence of geometry and orientation on flank insolation of streets in an arid climate city. Am. J. Engineer. Applied Sci., 3: 540-544. DOI: 10.3844/ajeassp.2010.540.544

Mohaprtra, D. and P.S. Rao, 2005. A thin layer drying model of parboiled wheat. J. Food Eng., 66: 513-518. DOI: 10.1016/J.JFOODENG.2004.04.023

Omar, S.R., O.H. Ahmed, S. Saamin and N.M.A. Majid, 2008. Gamma radiosensitivity study on chili (capsicum annuum). Am. J. Applied Sci., 5: DOI: 10.3844/ajassp.2008.67.70

Opafunso, Z.O., I.I. Ozigis and I.A. Adetunde, 2009. Pneumatic and hydraulic systems in coal fluidized bed combustor. Am. J. Engineer. Applied Sci., 2: 88-95. DOI: 10.3844/ajeassp.2009.88.95

Ornela-Paz, J.D.J., J.M. Martinez-Burrola and S. RuizCruz et al., 2010. Effect of cooking on the capsaicinoids and phenolics contents of Mexican peppers. Food Chem., 119: 1619-1625. DOI: 10.1016/j. foodchem.2009.09.054

Panchariya, P.C., D. Popocic and A.L. Sharma, 2002. The thin-layer modeling of black tea drying process. J. Food Eng., 52: 349-357. DOI: 10.1016/S0260-8774(01)00126-1 
Pompimon, W., J. Jomduang, U. Prawat and S. Mankhetkorn, 2009. Anti-phytopthora capsici activities and potential use as antifungal in agriculture of alpinia galanga swartz, curcuma longa linn, boesenbergia pandurata schut and chromolaena odorata: bioactivities guided isolation of active ingredients. Am. J. Agric. Biol. Sci., 4: 83-91. DOI: 10.3844/ajabssp.2009.83.91

Quasem, J.M., A.S. Mazahreh, K. Abu-Alruz, I.A. Afaneh and A.H. Al-Muhtaseb et al., 2009. Effect of methyl cellulose coating and pre-treatment on oil uptake, moisture retention and physical properties of deepfat fried starchy dough system. Am. J. Agric. Biol. Sci., 4: 156-166. DOI: 10.3844/ajabssp.2009.156.166

Sayyar, S., Z.Z. Abidin, R. Yunus and A. Muhammad, 2009. Extraction of oil from jatropha seedsoptimization and kinetics. Am. J. Applied Sci., 6: 1390-1395. DOI: 10.3844/ajassp.2009.1390.1395

Sghaier, J., S. Messai, D. Lecomte and A. Belghith, 2009. High temperature convective drying of a packed bed with humid air at different humidities. Am. J. Engineer. Applied Sci., 2: 61-69. DOI: 10.3844/ajeassp.2009.61.69
Singh, J. and A.K. Pandey, 2010. Effect of temperature and storage time on shelf life of mycoherbicidal products of colletotrichum dematium FGCC\#20. Am. J. Agric. Biol. Sci., 5: 315-320. DOI: 10.3844/ajabssp.2010.315.320

Stephen, A.K. and S. Emmanuel, 2009. Improvement on the design of a cabinet grain dryer. Am. J. Engineer. Applied Sci., 2: 217-228. DOI: 10.3844/ajeassp.2009.217.228

Theansuwan, W., K. Triratanasirichai and K. Tangchaichit, 2008. Continuous production of lime juice by vacuum freeze drying. Am. J. Applied Sci., 5: 959-962. DOI: 10.3844/ajassp.2008.959.962

Wang, Z., J. Sun and X. Liao et al., 2007. Mathematical modeling on hot air drying of thin layer apple pomace. Food Res. Int., 40: 39-46. DOI: 10.1016/j.foodres.2006. 07.017

Watanoa, S., Y. Imada and K. Hamadab et al., 2003. Microgranulation of fine powders by a novel rotating fluidized bed granulator. Powder Technol., 131: 250-255. DOI: $10.1016 / \mathrm{S} 0032$ 5910(03)00007-X

Yahya, Z., A. Husin, J. Talib, J. Othman and O.H. Ahmed et al., 2010. Soil compaction and oil palm (elaeis guineensis) yield in a clay textured soil. Am. J. Agric. Biol. Sci., 5: 15-19. DOI: 10.3844/ajabssp.2010.15.19 